International Journal of Advanced Academic Research (Sciences, Technology and Engineering) | ISSN: 2488-9849

Journal DOI: 10.46654/ij.24889849

Vol. 6, Issue 9 (September, 2020) | www.ijaar.org

Article DOI: 10.46654/ij.24889849.e6919

\title{
APPRAISAL OF THE OPERATION OF TRICYCLE AS A MEANS OF COMMERCIAL TRANSPORTATION IN MINNA, NIGERIA
}

\author{
${ }^{1}$ ISAAC, Ibelieve*, ${ }^{2}$ HABILA Jerry, ${ }^{2}$ OPARA Chibiko Increase \& ${ }^{2}$ AKPAKA Ugwuadi Kalu \\ ${ }^{1}$ Department of Urban and Regional Planning, Federal University of Technology, Minna. \\ ${ }^{2}$ Department of Urban and Regional Planning, Federal Polytechnic, Nekede, Imo State.
}

\section{Corresponding Author: +2347066410001}

Email: jerroh01@gmail.com

\begin{abstract}
Transport demand in different parts of the world is growing at a very rapid rate. However, it has been noted that the demand for efficient and effective means of transport has not been met with a commensurate supply of the service. Particularly, governments across the globe have not been able to provide its citizenry with adequate, convenient and affordable mass transport system. Transport services in Nigeria is inadequate both in qualitative and quantitative terms considering the rate of population growth. Therefore, as a result, people have devised alternative means of transporting themselves and their goods between their points of origin and destination. One of such alternative means is the paratransit, which is an umbrella term for commercial transport system whose maximum carrying capacity is between two to ten passengers. Tricycle is one major component of this peculiar alternative, that is, the paratransit. This paper aimed at appraising the operation of tricycle as a means of commercial transportation in Minna. The objectives were to evaluate the relationship between the age of the tricycle operators and the number of hours they operate daily and to evaluate the perception of the tricycle users in the study area. Tricycles aids economic empowerment of the operators in Minna. This study has also shown that tricycle riding serves as an employment for the operators where they earn considerable income (on the average) irrespective of age. Similarly, it has shown that the consumers of tricycle services are satisfied with the services rendered to them using tricycles; although they will resort to a better alternative if that is provided, implying that public transport will thrive well in the study area if adequately and efficiently provided. Therefore, it is recommended that the more efficient and effective means of mass transport should be provided for the city to ease the transportation stress of the inhabitants. Further studies into the spatial implication of the proliferation of tricycles on the roads ofland cityscape of Minna is recommended.
\end{abstract}

Keywords: Transportation, Paratransit, Satisfaction, Urbanization, Tricycles. 


\section{INTRODUCTION}

Transportation is a basic necessity of man. It is subject to the economic forces of demand and supply. However, the demand for transportation is a derived demand, implying that transportation is not consumed for just the consumption sake but for other interlocking needs. In other words, transportation is not an end in itself, but a means to an end. As Dike (2012) observed, urbanization is usually accompanied by an escalating demand for passenger transportation; with time, this demand gets more complex and difficult to satisfy. Adeyinka (2013) extensively argued that urban transport services in Nigeria is inadequate both in qualitative and quantitative terms considering the rate of population growth and the economic condition of an average Nigerian on the affordability of transport services to meet his or her travel demands over the past four decades. Paratransit system is characterized by fragmented ownership, reduced vehicle size, oversupply in certain parts of the city, and disruptive competition among operators (Ipingbemi and Adebayo, 2016). This is in spite of Mgbemena's (2013) assertion that transportation contributes significantly to the national economy. Tricycle (popularly called Keke NAPEP in Nigerian parlance) is one of the major alternatives adopted by the urban residents in Nigeria as a means of commercial passenger (and sometimes, light freight) transport. Therefore, there is a burgeoning need to study the socioeconomic impact of tricycle riding in Minna, as well as evaluate the level of satisfaction derived from tricycle services by the commuters.

\section{Statement of Problem}

Transportation is an age-long activity. Consequently, transport demand dates back to the history of man. However, it has been noted that the demand for efficient and effective means of transport has not been met with a commensurate supply of the service. Particularly, governments across the globe have not been able to provide its citizenry with adequate, convenient and affordable mass transport system. Therefore, as a result, people have devised alternative means of transporting themselves and their goods between their points of origin and destination. One of such alternative means is the paratransit, which is an umbrella term for commercial transport system whose maximum carrying capacity is between two to ten passengers. Tricycle is one major component of this peculiar alternative, that is, the paratransit.

Transport demand in different parts of the world is growing at a very rapid rate (Ipingbemi and Adebayo, 2016), and this is borne out of the necessity for people to meet social and economic (Fadare and Salami, 2004) as well as political, religious and tourism needs. The problems of poor transportation in urban centres, couple with the relative inadequacy of mass transit systems have led to the development of paratransit as an alternative. Nwaogbe et al. (2012) viewed tricycles as 'informal transport services', while maintaining that they play a significant role as 'gap fillers'. Thus, there is a need to study their economic impacts on their operators as well as the quality of service they render to the commuters. 


\section{Aim and Objectives}

The aim of this paper is to appraise the operation of tricycle as a means of commercial transportation in Minna. To achieve this aim, the following objectives are pursued:

i. Identify the socioeconomic characteristics of tricycle operators in the study area.

ii. Evaluate the relationship between the age of the tricycle operators and the number of hours they operate daily.

iii. Assess the perception of the users of tricycles as a means of transport.

\section{Hypotheses}

$\mathrm{H}_{0}$ (1): There is no statistically significant relationship between the age of tricycle operators and the number of hours they spend working per day

$\mathrm{H}_{0}(2)$ : There is no statistically significant difference in satisfaction with tricycle services among different income groups

\section{The Study Area}

Minna is a misspelling of the Gbagyi word 'Myina' which was the original name, meaning a cottage on the hill top (Fabiyi, 1984 cited in Sanusi, 2011). By implication, the original settlers of Minna were on the hilltops of the area. Sanusi (2011) reported that the hills provided secured home for the Gwari settlers, the indigenous owners of Minna and protected them from the invasion from the Nagwamatse led group from Kotangora town; a settlement some 160km away from Minna. He, however, noted that from about 1905 when railway lines reached Minna and when effective colonial occupation started giving security to Minna, residency on hill tops ceased to be a norm.

Acording to Maxlock (1979), Minna is located on Latitude $9^{\circ} 37^{\prime}$ North and Longitude $6^{\circ} 33^{\prime}$ East and occupies a land area of about 884 hectares. It is about $145 \mathrm{~km}$ by road from Abuja, the Federal capital of Nigeria. Minna metropolis has grown to engulf suburb settlements such as Bosso, Maitumbi, Dutsen Kura, Kpakungu, Shango and Chanchaga (Popoola et al., 2016). The map of the study area is presented in Figure 1. 


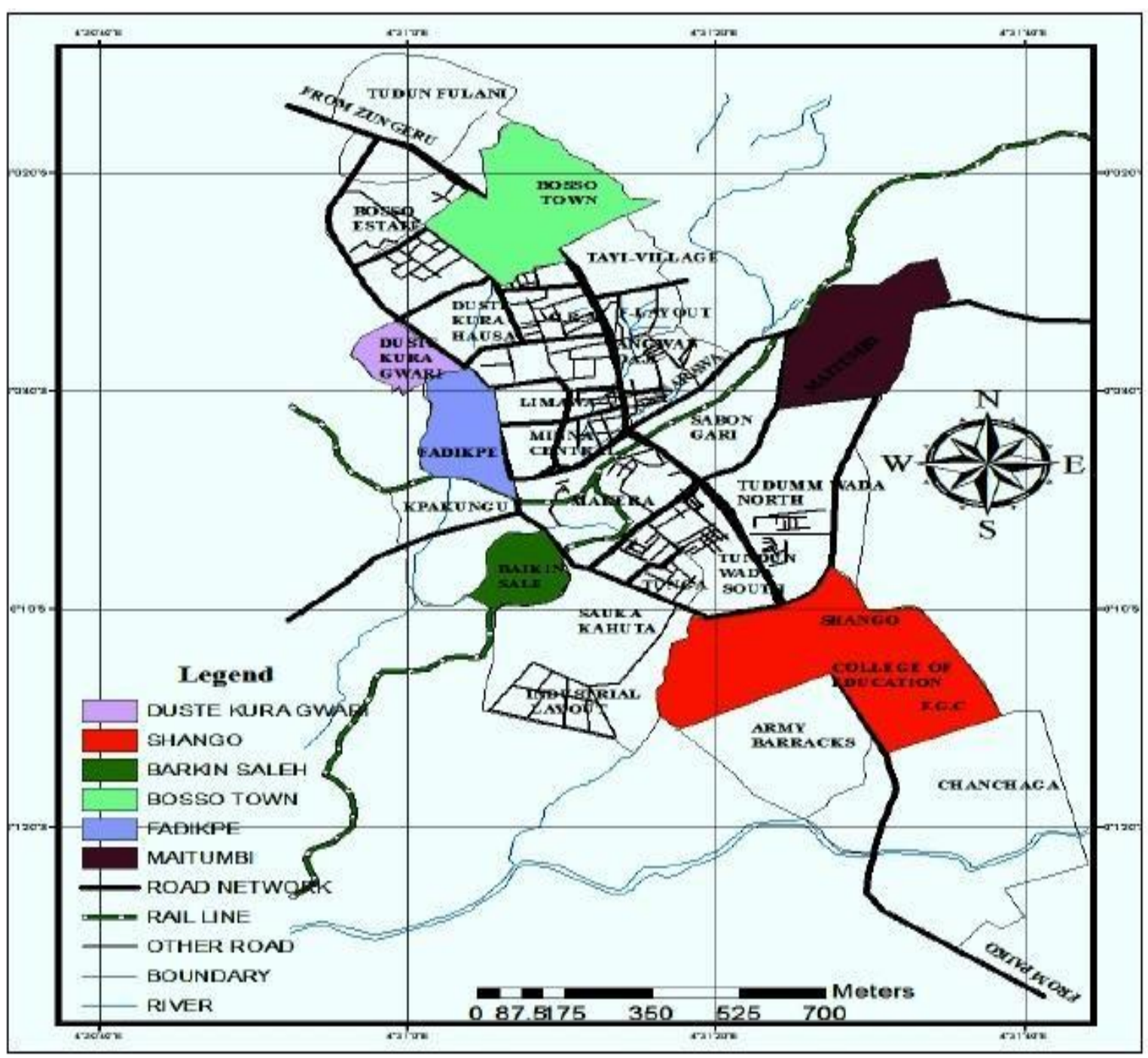

Fig. 1: Street Map of Minna, Niger State.

Source: Popoola et al. (2016)

\section{LITERATURE REVIEW}

Tricycles have helped in easing transport challenges in developing countries as well as in reducing time and resource wastage. For instance, a study by Aikins and Akude (2015) revealed that tricycles have helped in reducing all incidents of agricultural losses to a significant level in Ghana.

They also maintained that because tricycles are always available and affordable to the low income earners, their goods are easily transported to their homes on time with the aid of 
tricycles; thereby reducing losses resulting from thefts, bushfires, animal destruction and physical damages to the barest minimum.

Tricycles, known as "Keke" in Nigeria local parlance, are lightweight, flexible and open-sided vehicles designed to carry three adult passengers and a driver (Omoke et al., 2019). Tricycles have been represented in the literature with a variety of names, namely low-cost transport (Ocampo, 1982), intermediate public transport (Iwata, 1995; Ume and Nwachukwu, 2011), paratransit (Shimazaki and Rahman, 1996) and informal public transportation (Cervero, 2000; Kumarage et al., 2010). These studies maintained that paratransit serves as an alternative to mass transport.

It has been reported by Williams et al. (2019) that the widespread adoption of tricycles in the Northern part of Nigeria is because the driver is separated from passenger; thus, it preserved the religious ideals of sexual segregation of men and women. They noted that tricycles are popularly known as Adaidaita Sahuin Kano. Adaidaita Sahu is a Hausa word which means to straighten the line, or to maintain a queue. Just as Agbiboa (2017a; 2017b) observed the decorations of paratransit buses in Lagos (popularly known as Danfo), Williams et al. (2019) observed that tricycles in Northern Nigeria are decorated with a plethora of inscriptions locally known as kwalliya (beautification). This corroborates the earlier observation of Schulze (2012) who noted that the iconography of mosques, palm trees and swords that dominate vehicles in Northern Nigeria as an integral part of an Islamic paradigm that is associated to a typical religious visual culture in the north. Furthermore, Mukhtar et al. (2015) have argued that tricycle riding serves as an employment to many northern youths, thus serving as a means of poverty alleviation among the youths in the region. Similarly, some commuters expressed preference for tricycle as a means of transport because of its relative affordability, availability and safety (Sun, 2009).

\section{METHODOLOGY}

\section{Sources and methods of data collection}

The data for this study were collected from primary and secondary sources. The secondary sources include data obtained from books, journals, conference proceedings and reports. The primary data, on the other hand, were collected directly from the field through a well-structured questionnaire.

\section{Sampling technique}

Purposive sampling was adopted to sample 100 participants for the study. Of this 100 sample size, 50 were tricycle riders, while the other 50 were commuters who used tricycles as their means of transport. This equal share of participant is to allow for a fair representation of the perception of the riders and the users of tricycles in Minna. The choice of purposive sampling was based on the assumption that tricycle riders have similar characteristics and the tricycles 
themselves exhibit similar attributes. Similarly, although the sample frame of tricycle riders might be available, the sample frame for the users of tricycles is difficult to obtain.

\section{Method of data analysis}

Both descriptive and inferential statistical techniques were used to analyze the data obtained from the questionnaire survey. The descriptive statistics were presented in form of frequency tables. On the other hand, the inferential statistical technique adopted for the study is Analysis of Variance (ANOVA), which was used to test the hypotheses presented for the study; and thus, provide statistical answers to the research questions set for the study. Analysis was carried out with the aid of the Statistical Package for the Social Sciences (SPSS).

\section{DATA ANALYSIS AND PRESENTATION}

\section{Age of the respondents}

From the data presented in Table 1, it can be observed that majority of the tricycle riders are between the age of 18-37 which account for $62 \%$ of the tricycle riders in the study area (26\% for $18-27 y r s$ and $36 \%$ for $28-37 y r s$ respectively). This shows that the tricycle riding is dominated by people of youthful age.

Table 1: Age of the respondents

\begin{tabular}{ccc}
\hline Age & Frequency & Percentage \\
\hline $18-27$ & 13 & 26.0 \\
$28-37$ & 18 & 36.0 \\
$38-47$ & 14 & 28.0 \\
48 and above & 5 & 10.0 \\
\hline Total & $\mathbf{5 0}$ & $\mathbf{1 0 0 . 0}$ \\
\hline
\end{tabular}

Source: Field Survey, 2020

\section{Marital status}

As indicated in Table 2, majority of the tricycle riders in the study area are married, accounting for about $48 \%$ of the study population. On the other hand, $34 \%$ and $12 \%$ of the respondents are single and divorced respectively. Consequently, only about $6 \%$ of the population under study reported being separated. This indicates that the tricycle riding industry is open to everyone, irrespective of their marital status. 
Journal DOI: 10.46654/ij.24889849

Vol. 6, Issue 9 (September, 2020)| www.ijaar.org

Article DOI: 10.46654/ij.24889849.e6919

Table 2: Marital status

\begin{tabular}{ccc}
\hline Marital status & Frequency & Percentage \\
\hline Single & 17 & 34.0 \\
Married & 24 & 48.0 \\
Divorced & 6 & 12.0 \\
Separated & 3 & 6.0 \\
\hline Total & $\mathbf{5 0}$ & $\mathbf{1 0 0 . 0}$
\end{tabular}

Source: Field Survey, 2020

\section{Average daily income}

Majority of the tricycle riders (72\% in total) in Minna earns above N2,000 daily (Table 3).

Cumulatively, they earn well above N60,000 monthly. In comparison with the minimum wage in Nigeria $(\mathrm{N} 18,000)$, it can be concluded that the tricycle riders earn above the minimum wage. This indicates that tricycle riding has the capability of lifting the operators above poverty.

Table 3: Average daily income

\begin{tabular}{ccc}
\hline Tricycle rider income & Frequency & Percentage \\
\hline Below N2,000 & 14 & 28.0 \\
N2,000 - 4,000 & 18 & 36.0 \\
N4,005 - 6,000 & 15 & 30.0 \\
Above N6,000 & 3 & 6.0 \\
\hline Total & $\mathbf{5 0}$ & $\mathbf{1 0 0 . 0}$
\end{tabular}

Source: Field Survey, 2020

\section{Tricycle ownership}

The result presented in Table 4 indicated that majority of the tricycles in the study area are not owned by the operators; they are owned by someone else (62\%). However, 38\% of the operators reported that they are the owners of the tricycles they are operating.

Table 4: Tricycle ownership

\begin{tabular}{ccc}
\hline ownership & Frequency & Percentage \\
\hline Self-owned & 19 & 38.0 \\
Owned by someone else & 31 & 62.0 \\
\hline Total & $\mathbf{5 0}$ & $\mathbf{1 0 0 . 0}$
\end{tabular}

Source: Field Survey, 2020 


\section{Contract arrangement (for those that are not the owners)}

Majority of the tricycle operators in Minna have their contracts stipulated as lease (36\%) and monthly return (20\%), cumulatively rounding up to about $56 \%$. It should, however, be noted that $6 \%$ of the tricycle riders are engaged in a contract stipulating weekly return (Table 5). Finally, $38 \%$ of the respondents are not engaged in any form of contract, indicating that they are the owners of their tricycles.

Table 5: If owned by someone else, what is the contract arrangement?

\begin{tabular}{ccc}
\hline Contract Arrangement & Frequency & Percentage \\
\hline Monthly return & 10 & 20.0 \\
Weekly return & 3 & 6.0 \\
Lease & 18 & 36.0 \\
Not Applicable & 19 & 38.0 \\
\hline Total & $\mathbf{5 0}$ & $\mathbf{1 0 0 . 0}$
\end{tabular}

Source: Field Survey, 2020

\section{Average hours operated daily}

The result presented in Table 6 shows that majority of the tricycle operators $(36 \%)$ functions between 7-9hours daily. This is closely followed by those who operate for between 3-6hours daily $(32 \%)$. Only about $4 \%$ of the operators operated for over 12hours daily; while only $6 \%$ operated less than 3hours daily. This indicates that tricycle operators varies by the number of hours they work daily; in other words, different riders do not spend the same number of hours working.

Table 6: Average hours operated daily

\begin{tabular}{ccc}
\hline Hours operated & Frequency & Percentage \\
\hline Less than 3hrs & 3 & 6.0 \\
3-6hrs & 16 & 32.0 \\
7-9hrs & 18 & 36.0 \\
9-12hrs & 11 & 22.0 \\
Over 12hrs & 2 & 4.0 \\
\hline Total & $\mathbf{5 0}$ & $\mathbf{1 0 0 . 0}$ \\
\hline
\end{tabular}

Source: Field Survey, 2020

\section{Average daily Expenditure}

Majority of the tricycle riders in the study area (representing 68\%) reported that they spend $\mathrm{N} 1,000-2,000$ daily on the tricycles. This expenditure covers maintenance and fueling costs. It 
was also observed that $30 \%$ of the operators spent less than N1,000 on their tricycles daily. It was observed, however, that only $2 \%$ of the operators spent above N2,000 daily on the tricycles. This infers that the expenditure of the operators is commensurate with their income inter alia (presented in Table 3).

Table 7: Average daily Expenditure

\begin{tabular}{ccc}
\hline Expenditure on tricycle & Frequency & Percentage \\
\hline Less than N1,000 & 15 & 30.0 \\
$\mathrm{~N} 1,000-2,000$ & 34 & 68.0 \\
$\mathrm{~N} 2,005-3,000$ & 1 & 2.0 \\
\hline Total & $\mathbf{5 0}$ & $\mathbf{1 0 0 . 0}$
\end{tabular}

Source: Field Survey, 2020

\section{Experience in Business}

Table 8 shows that majority of the tricycle operators in Minna (34\%) have been in that business for 2-4years. Overall, about $86 \%$ of the tricycle riders have more than 2years experience in the business. However, it was observed that $14 \%$ of the operators has less than 2 years experience in the operation of tricycles.

Table 8: Experience in the business of tricycle operation

\begin{tabular}{ccc}
\hline Experience & Frequency & Percentage \\
\hline Less than 2yrs & 7 & 14.0 \\
2-4yrs & 17 & 34.0 \\
5-6yrs. & 15 & 30.0 \\
7-8yrs & 11 & 22.0 \\
\hline Total & $\mathbf{5 0}$ & $\mathbf{1 0 0 . 0}$
\end{tabular}

Source: Field Survey, 2020

\section{Users' rating of tricycle as an effective means of transport}

The analysis in Table 9 indicates that $40 \%$ and $30 \%$ of the users strongly agree and agree respectively that tricycle is an effective means of transportation. Conversely, $6 \%$ and $2 \%$ of the users strongly disagree and disagree with the notion that tricycle is an effective means of transport, indicating that they prefer other better means if they are provided to them. Therefore, while about $8 \%$ of the users expressed disagreement with the effectiveness of tricycles as a means of transport, $70 \%$ expressed acceptance of tricycles as an effective means of transport in Minna. This implies that majority of the users of tricycles in the study area see tricycles as an effective means of transport. 
Journal DOI: 10.46654/ij.24889849

Vol. 6, Issue 9 (September, 2020)| www.ijaar.org

Article DOI: 10.46654/ij.24889849.e6919

Table 9: Tricycle as an effective means of transport

\begin{tabular}{ccc}
\hline Effectiveness of tricycles & Frequency & Percentage \\
\hline Strongly agree & 20 & 40.0 \\
Agree & 15 & 30.0 \\
Undecided & 11 & 22.0 \\
Disagree & 1 & 2.0 \\
Strongly disagree & 3 & 6.0 \\
\hline Total & $\mathbf{5 0}$ & $\mathbf{1 0 0 . 0}$ \\
\hline
\end{tabular}

Source: Field Survey, 2020

\section{Users' Satisfaction with Operation of tricycles}

Majority of the users of tricycles as a means of transport (28\%) expressed high rate of satisfaction with tricycle services, while $22 \%$ expressed moderate satisfaction (Table 10). On the contrary, $12 \%$ of the users expressed high rate of dissatisfaction, while $14 \%$ expressed moderate dissatisfaction with their experience of tricycle services, implying that they will prefer a better and more efficient alternative means.

Table 10: Satisfaction with the operation of tricycles

\begin{tabular}{ccc}
\hline Satisfaction with tricycles & Frequency & Percentage \\
\hline Highly satisfied & 14 & 28.0 \\
Satisfied & 11 & 22.0 \\
Undecided & 12 & 24.0 \\
Dissatisfied & 7 & 14.0 \\
Highly dissatisfied & 6 & 12.0 \\
\hline Total & $\mathbf{5 0}$ & $\mathbf{1 0 0 . 0}$ \\
\hline
\end{tabular}

Source: Field Survey, 2020

\section{Reason for the choice of tricycle as a means of transport}

Based on the information presented in Table 11, affordability (38\%) and availability (32\%) are the strongest factors shaping the choice of tricycles as a means of transport. These two factors are the reasons shaping the adoption and use of tricycle as a means of transport as expressed by the users.

However, ability to reach the users' destination (12\%) is the weakest reason for adoption and use of tricycles as a means of transport by the users. Furthermore, $18 \%$ of the users stated that the quality of tricycle services is the reason for their adoption of tricycles. 
Journal DOI: 10.46654/ij.24889849

Vol. 6, Issue 9 (September, 2020) | www.ijaar.org

Article DOI: 10.46654/ij.24889849.e6919

Table 11: Reason for the choice of tricycle as a means of transport

\begin{tabular}{ccc}
\hline Reason for modal choice & Frequency & Percentage \\
\hline Availability & 16 & 32.0 \\
Affordability & 19 & 38.0 \\
Service quality & 9 & 18.0 \\
Ability to reach my destination & 6 & 12.0 \\
& & \\
\hline Total & $\mathbf{5 0}$ & $\mathbf{1 0 0 . 0}$ \\
\hline
\end{tabular}

Source: Field Survey, 2020

\section{Average monthly income of tricycle users}

Table 12 shows that majority of the respondents (46\%) earn less than N18,000 monthly, followed by $30 \%$ who earn between N18,000 - 28,000. However, only about $8 \%$ of the tricycle users earn above N48,000. In essence, 54\% of the respondents earn N18,000 and above, indicating that majority of the users earn the minimum wage of Nigeria.

Table 12: Average monthly income of tricycle users

\begin{tabular}{ccc}
\hline Income of users & Frequency & Percentage \\
\hline less than N18,000 & 23 & 46.0 \\
$\mathrm{~N} 18,000-28,000$ & 15 & 30.0 \\
$\mathrm{~N} 28,005-38,000$ & 6 & 12.0 \\
$\mathrm{~N} 38,001-48,000$ & 2 & 4.0 \\
Above N48,000 & 4 & 8.0 \\
\hline Total & 50 & 100.0
\end{tabular}

Source: Field Survey, 2020

\section{Average Hours Operated Daily Versus Age}

A one-way Analysis of Variance (ANOVA) was conducted to test the statistical relationship between the age of tricycle operators and the number of hours they spend working per day. The result presented in Table 13 shows that there is no statistically significant relationship between the age of the tricycle operators and the number of hours they operate daily at $\alpha=0.05$. The calculated value $(p=0.21)$ is greater than $\alpha(0.05)$. Hence, there is no enough statistical evidence to reject $\mathrm{H}_{0}$ and accept $\mathrm{H}_{1}$. Therefore, age is not a significant determinant of the number of hours spent daily in tricycle operation among the tricycle riders in the study area. 
Journal DOI: 10.46654/ij.24889849

Vol. 6, Issue 9 (September, 2020) | www.ijaar.org

Article DOI: 10.46654/ij.24889849.e6919

Table 13: Relationship between Age and Number of Hours Operated Daily

\begin{tabular}{lcrcrc}
\hline & Sum of Squares & df & Mean Square & F & Sig. \\
& & & & & \\
\hline Between Groups & 4.270 & 3 & & & \\
& & & & & \\
Within Groups & 41.750 & 46 & .423 & \\
Total & 46.020 & 49 & & \\
& & & & & \\
\hline
\end{tabular}

Source: Field Survey, 2020

\section{Income of Users Versus their Level of Satisfaction with Tricycle Services}

A one-way ANOVA test was carried out to determine whether there is a statistically significant difference in satisfaction among different users of tricycle services as a result of income. The result in Table 14 indicates that there is no statistically significant difference in satisfaction derived from tricycle services among different income groups at $\alpha=0.05$. The calculated value $(p=0.124)$ is greater than $\alpha(0.05)$. Therefore, the test revealed that income is not a significant determinant of the level of satisfaction among the users of tricycles in Minna. In other words, there is no enough statistical evidence to suggest that as income increase, satisfaction reduces, or otherwise.

Table 14: Relationship Between the Income of Tricycle Users and their Satisfaction with Tricycle Services

\begin{tabular}{lccccc}
\hline & Sum of Squares & df & Mean Square & F & Sig. \\
\hline Between Groups & 13.107 & 4 & 3.277 & 1.918 & $\mathbf{. 1 2 4}$ \\
Within Groups & 76.893 & 45 & 1.709 & & \\
\hline Total & 90.000 & 49 & & \\
\hline
\end{tabular}

Source: Field Survey, 2020 


\section{CONCLUSION AND RECOMMENDATIONS}

Transportation is an important aspect of humanity. That the demand for transport is a derived one implies that people hardly travel for the sake of travel; they travel because there is a need to travel. As the world continue to urbanize, so also the demand for transportation (especially in the urban areas) will continue to rise. Notwithstanding this glaring reality, governments have not been able to meet up with the supply of mass transport systems. This has made private transporters and commuters to devise cheap and alternative means which are generally referred to as paratransit. Tricycles are used as an alternative means of transport in Nigeria, especially by the poor households. They are also an avenue for economic empowerment of the operators. This study has shown that tricycle riding serves as an employment for the operators where they earn considerable income (on the average) irrespective of age. Similarly, it has shown that the consumers of tricycle services are satisfied with the services rendered to them using tricycles. However, they maintained that they will resort to a better alternative if that is provided. This implies that public transport will thrive well in the study area if adequately and efficiently provided. Based on the findings of this study, the study recommends a more efficient and effective means of mass transport should be provided for the city to ease the transportation stress of the inhabitants. Secondly, creation of more employment opportunities for the teeming population of the state is recommended. The study did not assess the spatial impacts of tricycle proliferation in the urban scene. Therefore, further studies into the spatial implication of the proliferation of tricycles on the roads of/and cityscape of Minna is recommended. 


\section{REFERENCES}

Adeyinka, A. M. (2013). Assessment of the Quality of Urban Transport Services in Nigeria. Academic Journal of Interdisciplinary Studies, 2(1), 49-58.

Agbiboa, D. E. (2017a). Mobile Bodies of Meaning: City Lie and the Horizons of Possibility. Journal of Modern Studies, 55(3), 371-393.

Agbiboa, D. E. (2017b). No Condition is Permanent: Informal Transport Workers and Labour Precarity in Africa's Largest City. International Journal of Urban and Regional Research, 40(5), 936-957.

Aikins, K. A. \& Akude, G. S. (2015). The impact of motor tricycles on transportation of agricultural produce in the Pru District of Ghana. Global Journal of Biology, Agriculture and Health Sciences, 4(3), 22-26.

Cervero, R. (2000). Informal Transport in the Developing World. Kenya: UNCHS.

Dike, D. N. (2012). An empirical study of the use of tricycle as a public transport mode in Nigerian cities. Journal of Social Sciences and Public Affairs, 2(2), 66-76.

Fadare O, and Salami B. (2004). Telephone uses and the travel behavior of residents in Osogbo, Nigeria: an empirical analysis. Journal of Transport Geography, 12, 159-164.

Ipingbemi, O and Adebayo, A. (2016). Tricycle as a mode of public transportation in Ibadan Metropolis, Nigeria. Ife Research Publications in Geography, 14(2016) 87 - 100.

Iwata, S. (1995). Development and sustainability of public transportation in southeast Asian cities. Journal of the Eastern Asia Society for Transportation Studies, 1(2): 547-564.

Kumarage, A. S., Bandara M., \& Munasinghe, D. (2010). Analysis of the economic and social parameters of the Three Wheeler Taxi service in Sri Lanka. Research in Transportation Economics, 29, 395-400.

MaxLock (1979). Minna Master plan. Max Lock Group.

Mgbemena, J. (2013). Language, communication on wheels and national development: The inscriptions on tricycle (Keke) example. International Journal of English and Literature, 4(10), 529-537.

Mukhtar, A., Waziri, M., Abdulsalam, B., \& Dankani, I. M. (2015). Assessment of tricycle as a tool of poverty alleviation in Maiduguri, Borno State, Northeast Nigeria. IOSR Journal of Humanities and Social Science, 20(8), 14-18.

Nwaogbe, O. R., Ibe, C. C. and Ukeagbu, S. I. (2012). Quality of the paratransit service (tricycle) and its operation in Aba, Nigeria: An analysis of customers' opinions. Journal of Transport and Supply Chain Management, 262-276. 
Ocampo, R. B. (1982). Low-cost transport in Asia: A comparative report on five cities. IDRC: Canada.

Omoke, N. I., Lasebikan, O. A., Onyemaechi, N. O. \&Ajali, N. (2019). Auto tricycle injuries and the vulnerability of occupants and pedestrians in a developing country: A multi-center study. Nigerian Journal of Clinical Practice, 22, 971-976

Popoola, N. I., Jinadu, A.M., Sanusi, Y. A., Adeleye, B.M., \& Odumosu, J. O. (2016). Evaluation of spatial growth dynamics in the peri-urban residential neighbourhoods in Minna, Nigeria. Academic Research International, 7(1), 259-270.

Sanusi, Y. A. (2011). Pressure-State-Response framework analysis of residential development on ecologically unstable land in Minna, Nigeria. Ozean Journal of Applied Sciences 4(2), 145169 .

Schulze, K. (2012). Mosques, Palm Trees and Swords: Religious Symbolism in Northern Nigerian Lorry Decorations. Annual Review of Islam in Africa, 11, 12-17.

Shimazaki, T. and Rahman, M. (1996). Physical characteristics of paratransit in developing countries of Asia. Journal of Advanced Transportation,30(2):5-24.

Sun Newspaper (2009) Saving the lives of tricycle users. http://www,sunnewsonline.com/webpage/abujareports/2009/May/04.abujareport-04052009-002.htm, Accessed on 25 ${ }^{\text {th }}$ August, 2019

Ume, N. C. and Nwachukwu, C. U. (2011). Intermediate Means of Transport (IMT) and Transport Systems (TSS): Their relevance in the development of Rural Transport System (RTS) in Ideato-North L.G.A of Imo State. Report and Opinion, 3(11), 14-18.

Williams, O., Lawan, I., Popoola, O. D., \&Kofar-Na'isa, A. U. (2019). Creativity and social identity in urban transport: Tricycle decoration in Kano metropolis. IFRA-Nigeria Working Papers Series, $\mathrm{N}^{\circ} 51$. 